\title{
Modern Schoolchildren's Passion \\ for Headphones and Earphones. What are the Consequences?
}

\author{
Irina A. Ignatova*a,b,c, Sergey N. Shilov*c, \\ Sergey G. Vakhrushev ${ }^{\mathrm{b}}$ and Ludmila I. Pokidysheva ${ }^{\mathrm{d}}$ \\ ${ }^{a}$ Scientific Research Institute of Medical Problems of the North \\ $3 g$ Partizan Zheleznyak Str., Krasnoyarsk, 660022, Russia \\ ${ }^{b}$ Krasnoyarsk State Medical University \\ named after prof. V.F. Voyno-Yasenetsky \\ 1 Partizan Zheleznyak Str., Krasnoyarsk, 660022, Russia \\ ${ }^{c}$ Krasnoyarsk State Pedagogical University \\ named after V.P. Astafev \\ 89 Lebedevoy Str., Krasnoyarsk, 660049, Russia \\ ${ }^{d}$ Siberian Federal University \\ 79 Svobodny, Krasnoyarsk, 660041, Russia
}

The paper focuses on the identification of factors affecting the manifestation of hearing loss among schoolchildren. These are the state of the mucous membrane of the upper respiratory tract, their age, anxiety and stress, amount of time spent on watching TV aday (listening to loud music and using head/ earphones).

Using mathematical method of correlation adaptometry the authors revealed the significant correlations between the detected peculiarities of hearing loss pathology among schoolchildren (form and severity of hearing loss) and their age, somatic and neurological status, as well as the degree of psychic and emotional stress. The data may be useful for psychologists, otorhinolaryngologists, audiologists, pediatricians.

Keywords: children, hearing loss, risk factors, schoolchildren.

This study was funded by the Russian Humanitarian Science Foundation and Krasnoyrsk krai, namely the grant No 15-16-24007 "The complex studies of the small-numbered peoples, residing in the Arctic zone of Eastern Siberia, in the fi eld of fundamental medicine, distance learning and social, cultural and economic activities".

DOI: 10.17516/1997-1370-2015-8-9-1911-1918.

Research area: pedagogy.

(C) Siberian Federal University. All rights reserved

* Corresponding author E-mail address: ignatova@mail.ru, shiloff.serg@yandex.ru 
The importance of the stated topic is high due to the high prevalence of hearing pathology, associated with its progress and modification of its course. This problem is extremely important for the young generation - the future of Russia. The number of patients with hearing impairments in Russia exceeds 13 million people. Especially alarming situation is that among children and adolescents the number of patients with hearing loss is greater than 1.000 .000 people (Tavartkiladze, G.A., 2012).

In France, each year in the middle of March people celebrate the National Day of hearing. "Digital player: what is the risk for hearing?" asked those responsible for the prevention of hearing loss. This question targets young music fans, endangering their ears. The figures in the Report of the Scientific Committee on Emerging Health Risks, having been made for the European Commission, emphasize the scale of danger: about 10 million young people are at risk of hearing loss either partly or completely.

What is a difference between hearing loss and deafness? In medicine, these terms are used for naming different extents of hearing loss. Hearing may be reduced to mild, moderate, average and severe extent (up to its complete loss).

There exist the following forms of hearing pathology: sensorineural hearing loss - a disease of the ear associated with lesions in which the root cause lies in the vestibulocochlear nerve, the inner ear, when for whatever reason the process of converting mechanical vibrations into energy of nerve impulses is disrupted, and the further transportation of the energy from the receptor to the centers of the cerebral cortex is hindered. Conductive hearing loss is a violation of sound passage to audio analyzing structure.

Sensorineural hearing loss is a disease poly-etiological character. It is caused by a lot of (more than a hundred) reasons. The occurrence of this disease is assigned to the role of etiological factors, such as infectious diseases, acoustic and mechanical traumas, vascular diseases (hypertension, atherosclerosis, vegetative-vascular dystonia, stress). In recent years, the identification of the role of a genetic predisposition has become extremely relevant.

Currently, otorhinolaryngologists in Krasnoyarsk actively develop methods of differential diagnosis, prevention and treatment of acute and chronic diseases of hearing; their indepth studies involve genetic reasons of hearing loss. In addition they try introducing new ways of treatment and prevention. Besides, they invented the term "Three M".

Medical genetics - a system of knowledge about the role of hereditary factors in forming human pathology.

Medical and genetic counseling - a communicative process, during which the doctorgeneticist tells the patients and their family about the risk of hereditary disease, its course, methods of prevention and treatment.

Mendelian inheritance - the inheritance of characteristics, coded in a single gene.

Hereditary forms are divided into: syndromic forms - 15-30 \% (400-700 nosological units) and non-syndromic forms - 70-85 \% (autosomal and recessive - $75 \%$, autosomal and dominant-25\%). The number of known genes is more than 60. Most significant genetic disorders are mutations in the gene GJB2 (connexin 26). Statistics of its frequency today is $10-37 \%$ (1 per 2.000 births), while the frequency of other genes is not more than $5 \%$.

The researchers studied the frequency of GJB2 gene mutation among the healthy population in Russia. Mutation of $35 \mathrm{delG}$ in the connexin gene is 26 , i.e. 1 per $25-46$ people $(2 \%-4 \%)$.

There are international studies of mutations in the GJB2 gene (the gene of connexin 26) in case of congenital and neonatal deafness. The 
results are following: in Spain $-35 \mathrm{delG}-44 \%$, 1 per 43 people (2.3\%); the Mediterranean area $53 \%, 1$ per 25 people (4\%); in US - 37\%, 1 per 30 people (2.5-3.3 \%); in England $-<10 \%, 1$ per 100 people; Japan - no, $28 \%-235 \mathrm{delC}$, V37I; China - 2 carriers per 203 (1\%); Korea - $20 \%$; Turkey - $33 \%$, including 167delT; Israel $-4 \%$ of carriers among Ashkenazi Jews. This is the statistics of international research in this area.

What is the prevalence of hereditary forms of sensorineural hearing loss? They are the reason for about $50 \%$ cases of congenital and neonatal hearing loss, or 20 deaf children out of $40-50$.

In Russia some research was done in the field of search for mutations in the GJB2 gene, which cause the hereditary deafness. The results are shown by the following figures.

Moscow - 35delG, $36 \%$ (1 per 46); St. Petersburg - $38 \%$ (1 per 25-30); Rostov Oblast $45 \%, 1$ per 35 (0-5\%); Ufa, Bashkortostan $69 \%$ (Russians), $50 \%$ (Tatars), $6 \%$ (Bashkirs carriers were not identified), Altai - $47 \%$ (Russians), $8.3 \%$ (Altaians); Chuvashia - $42 \%$ (Russians), $5 \%$ (Chuvashes); Yakutia - $42 \%$ (Russians), 1 per 35, and $2 \%$ (Yakuts), 1 per 247; Kirov Oblast $-32 \%$.

Our aim: to investigate the incidence rate and form of deafness among schoolchildren in Krasnoyarsk, and the relationship of its occurrence with the following biological factors: age, gender, heart rate, blood pressure, psychic and emotional stress.

Material. The study involved more than 500 schoolchildren in Krasnoyarsk. The sample of the report included 170 schoolchildren aged 6-17 years ( 86 boys and 84 girls). All students were divided into groups according to age (6-10 years, 11-14 years, 15-17 years).

We used the following methods. ENT: complex audiological examination was carried out with the application of an otoscope and diagnostic audiometer AD-226. Neurological methods: we evaluated somatic and neurological status; evaluated the students' emotional status according to Eysenck and Navy tests (on memory, thinking, attention) and with the help of psychological and diagnostic tests developed by E.N. Rogov. All schoolchildren had full physical examination, including obtaining the medical history; pediatric examination of major organs and systems; measurement of heart rate, blood pressure; evaluation of physical and sexual development; collection of data on motor activity, mental and physical performance; data on chronic diseases; information about the number of hours spent watching television, using the computer and listening to loud music through headphones. Statistical methods included correlation and logistic regression analysis and non-parametric methods of correlation analysis: Spearman methods - to study the relationship of quantitative traits, regardless of the type of their distribution, the quantitative and qualitative ordinal characteristics. The applied mathematical methods included: logistic regression analysis, which allowed creating a model to predict the probability of an event on the basis of the available data. The regression model is designed to solve the problem of predicting the values of a continuous dependent variable.

For the ENT examination the researchers together with prof., cand. of tech. sciences L.I. Pokidysheva developed an expert system containing the records of patients and able to make initial diagnosis in the field of otorhinolaryngology. System features enable: to gain knowledge about the studied area and the relevant decision making method; to explore the causal factors affecting the diagnosis; to save personal medical history of patients; to record any number of medical checks; to form the archive of case histories, to edit them and make the search; to make diagnoses according to medical checks, 
as well as to import and export these data in the format of Excel.

The method of correlation adaptometry was used to determine the degree of relationship between the studied parameters of hearing pathology and a form and severity of somatic and psycho-emotional abnormalities.

Results: the development of autonomic dysfunction syndrome - ADS (one of the leading etiological causes of hearing loss due to neurosensory genesis) depends mainly on the individual and typological characteristics of a child. In this regard, we investigated the emotional status of schoolchildren, as well as assessed the level of their emotional stress on a H.J. Eysenck's test on "neuroticismemotional stability". As a result of neurological examination of schoolchildren, we revealed the following: children with ADS have similar to healthy children orientation of the emotional status distribution, accompanied by a statistically significant predominance of extraverted type. In this group of children sensorineural hearing loss is more frequent.

The average value of the emotional instability among the adolescents in Krasnoyarsk goes beyond the high emotional instability and reaches a very high level of emotional instability $(18,5 \pm$ 0,31 points), while among children of elementary school age in Krasnoyarsk this value falls in the range of high emotional instability $(17,27 \pm 0,26$ points).

The increased level of personal anxiety among adolescents with ADS is combined with the development of insecurity, mood swings, tendency to delay emotions. The results reflect the formation of asthenic neurosis and subsequent personality traits in children with ADS and their strengthening with the age.

When considering the total value of strong relationships in correlation graph $\mathrm{G}$ of indicators of hearing among schoolchildren in different age groups, we obtained the results shown in Fig. 1.

The diagram shows the weight $G$ of the studied age groups $(p<0.05)$. The highest value of weight $G$ specifies the group of 11-14 year old children. We can assume that in this age the hearing system experiences the greatest stress. This is probably due to the fact that at this age many children, according to their medical history, use headphones or earphones to listen to loud music, which further contributes to the development of their hearing loss.

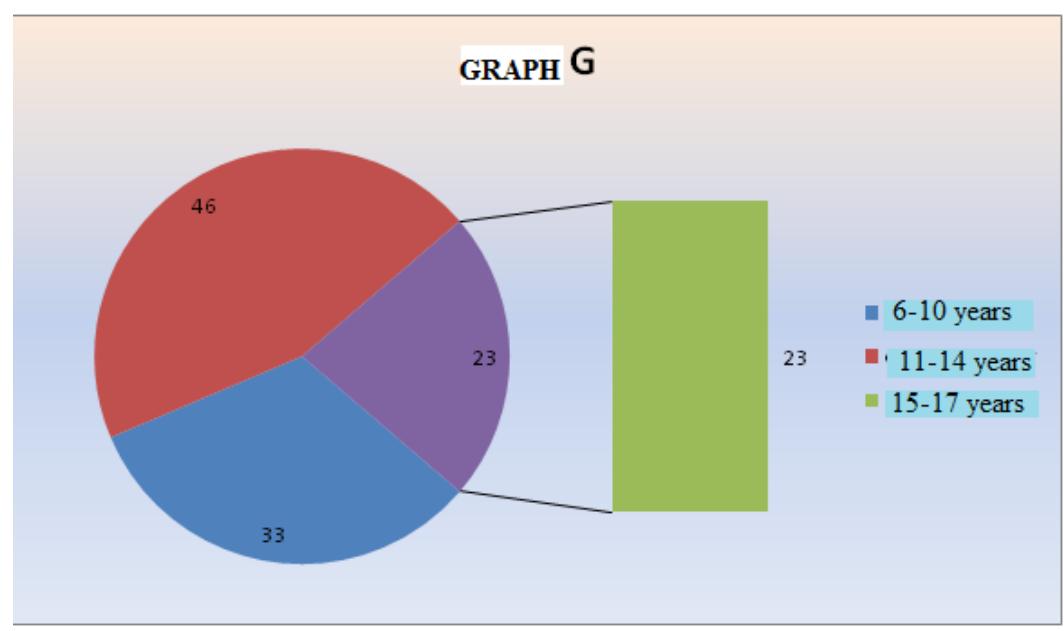

Fig.1. A weighted correlation graph $\mathrm{G}$ of indicators of hearing among schoolchildren in different age groups 


\section{Conclusion}

Thus, as a result of the study we revealed the dominant factors influencing the appearance of hearing loss: the state of the mucous membrane of the upper respiratory tract, age, anxiety and stress, the number of hours spent watching TV every day (listening to loud music and using headphones and earphones). The researchers proved the significant correlations between the detected peculiarities of the hearing pathology among schoolchildren (form, the severity of hearing loss) and school age, somatic status, neurological status, as well as the degree of psychological and emotional stress.

\section{References}

1. Butler R. A. (1983). The spatial attributes of Stimulus frequency in the median sagittal plane and their role in sound localization. Otolaryngol. ed. by J. Amer, Vol. 4, No. 3. Pp. 165-173.

2. Chouard, C. (1981). Transcutaneous electrotherapy for severe tinnitus. Acta otolaryng. (Stockh.) ed. by C. Chouard, B. Meyer, D. Maridat, Vol. 91, No. 5-6. Pp. 415-422.

3. Downs, H. (1981). Comprehensive treatment of children with reccurent serous otitis media. Otolaryngol. Head Neck Surg., Vol. 89, No. 4. Pp. 658-666.

4. Gorban', A.N., Smirnova, E.V., Tyukina, T.A. (2009). General Laws of Adaptation to Environmental Factors: from Ecological Stress to Financial Crisis. Math. Model. Nat. Phenom, Vol. 4, No. 6. Pp. 1-53.

5. Ignatova, I.A. Allergicheskaia rinosinusopatiia istinnogo i psevdoallergicheskogo geneza [Allergic rhinosinusopathy of real and pseudoallergic origin] ed. by I.A. Ignatova, S.V. Smirnova, V.T. Manchuk. St. Petersburg: "Dialog", 2007. 104 p.

6. Ignatova, I.A. Allergicheskaia rinosinusopatiia u zhitelei Krainego Severa i srednikh shirot Vostochnoi Sibiri (voprosy rasprostranennosti, etiologii i patogenza) [Allergic rhinosinusopathy among inhabitants of the Far North and Eastern Siberia (middle latitudes) (the issues of prevalence, etiology and pathogenesis)]. Matematicheskoe modelirovanie (Mathematical modeling) ed. by I.A. Ignatova, S.V. Smirnova, L.I. Pokidysheva, V.T. Manchuk. Krasnoyarsk, KSTU Publishing Center, 2005. $198 \mathrm{p}$.

7. Ignatova, I.A. Allergicheskaia rinosinusopatiia u zhitelei Sibiri i Severa [Allergic rhinosinusopathy among the inhabitants of Siberia and the North]. Ed. by I.A. Ignatova, S.V. Smirnova, L.I. Pokidysheva, V.T. Manchuk., Novosibirsk, Nauka Siberian Publishing Company of the RAS, 2005. $153 \mathrm{p}$.

8. Ignatova, I.A. Etnicheskie osobennosti patologii slukh u zhitelei Vostochnoi Sibiri i effektivnost' ee lecheniia [Ethnic peculiarities of the pathology of hearing among the inhabitants of Eastern Siberia and the effectiveness of its treatment]. Thesis of Dissertation of Candidate of Medical Sciences. M., 1998. 19 p.

9. Ignatova, I.A. Etnicheskie osobennosti patologii slukh u zhitelei Vostochnoi Sibiri [Ethnic peculiarities of the pathology of hearing among the inhabitants of Eastern Siberia]. Thesis of Dissertation of Doctor of Medical Sciences. St. Petersburg, 2006. 40 p.

10. Ignatova, I.A. Narusheniia slukha u detei i sovremennye puti reabilitatsii [Hearing impair ment ofchildren and the modern way of rehabilitation]. Materialy mezhregional'noi nauchnoprakticheskoi konferentsii s mezhdunarodnym uchastiem "Problemy i perspektivy differentsial'nogo, integrirovannogo, inkliuzivnogo obucheniia lits s ogranichennymi vozmozhnostiami zdorov'ia: 
regional'nyi opyt" (Proceedings of the interregional scientific-practical conference with international participation "Problems and prospects of differential, integrative, inclusive education of people with disabilities: regional experience"). Krasnoyarsk, 11-13 December 2008. Pp. 328-335.

11. Ignatova, I.A. Pokidysheva, L.I. (2011). Monitoring slukha i factory riska, sposobstvuiushchie razvitiiu patologii slukha u shkol'nikov [Monitoring of hearing and the risk factors that contribute to the development of the hearing pathology among schoolchildren in Krasnoyarsk]. Russian otorhinolaryngology, No. 3 (52). Pp.58-62.

12. Ignatova, I.A. Programmnyi kompleks "rabochee mesto otorinolaringologa" v pomoshch' prakticheskomu zdravookhraneniiu" ["The software module 'otorhinolaryngologist's workplace' in practical health care"]. Voprosy sokhraneniia i razvitiia zdorov'ia naseleniia respuliki Khakassia. (The problem of saving and development of public health of the republic of Khakassia) ed. by L.I. Pokidysheva, S.V. Ignatov, A.A. Sherstneva. Materialy konferentsii v ramkakh ezhegodnoi itogovoi nauchno-prakticheskoi konferentsii "Aktual'nye problem meditsiny. XII mezhregional'naia nauchnoprakticheskaia konferentsiia" (Proceedings of the conference within the annual final scientific and practical conference "Topical problems of medicine" XII interregional scientific and practical conference). Abakan. 3-4 June 2009. Pp.130.-133.

13. Ignatova, I.A. Struktura detskoi otorinolaringologicheskoi otopatologii respubliki Tyva. Voprosy sokhraneniia i razvitiia zdorov'ia naseleniia respuliki Tyva. [The structure of the children's ENT otopatology in the republic of Tyva. The problem of saving and development of public health of the republic of Tyva]. Kyzyl, 2008. Pp.93-94.

14. Ignatova, I.A. Vishniakova, K.P., Pozdniakova, L.G. Allergicheskaia rinosinusopatiia u starsheklassnikov Krasnoiarskogo regiona [Allergic rhinosinusopathy among students of high school in Krasnoyarsk region]. Shkola territoriia zdorov'ia: Materialy mezhregional'noi nauchnoprakticheskoi konferentsii (School "The Territory of Health: Materials of regional scientific and practical conference). Krasnoyarsk, 2010. Pp.107-109.

15. Ignatova, I.A., Andreychuk, N., Garina T.V. Otorinolaringologicheskie zabolevaniia verkhnikh dykhatel'nykh putei sredi starsheklassnikov Krasnoiarskogo regiona [Otorhinolaryngological diseases of the upper respiratory tract among high school students in Krasnoyarsk region]. Shkola territoriia zdorov'ia: Materialy mezhregional'noi nauchnoprakticheskoi konferentsii (School "The Territory of Health: Materials of regional scientific and practical conference). Krasnoyarsk, 2010. Pp.111-112.

16. Ignatova, I.A., Gantsova, E.A., Garina, T.V. Osobennosti patologii slukha u starsheklassnikov Krasnoiarskogo regiona [Peculiarites of hearing pathology among students of high school in Krasnoyarsk region]. Shkola territoriia zdorov'ia: Materialy mezhregional'noi nauchno-prakticheskoi konferentsii (School "The Territory of Health: Materials of regional scientific and practical conference). Krasnoyarsk, 2010. Pp.109-111.

17. Ignatova, I.A., Smirnova, S.V., Pokidysheva, L.I. Allergic Rhinosinusopathy in Inhabitants of Siberia. System Analysis. Germany: Lambert Academic Publishing, 2012, 168p. ISBN: 978 -3-65917861-0.

18. Markova, T.G. Kliniko-geneticheskii analiz vrozhdennoi i dorechevoi tugoukhosti \{Clinical and genetic analysis of congenital and prelingual hearing loss]. Thesis of Dissertation of Candidate of Medical Sciences. M., 2008. 23 p. 
19. Ovchnnikov, P.A. (2009). Osobennosti slukhovogo vospriiatiia u bol'nykh s pertseptivnoi tugoukhost'iu [Peculiarities of auditory perception in patients with perceptive deafness]. Nauchnaia biblioteka dissertatsii i avtoreferatov disserCat (Scientific Library of dissertations and theses disserCat). Available at: http://www.dissercat.com/content/osobennosti-slukhovogo-vospriyatiya-u-bolnykh-spertseptivnoi-tugoukhostyu\#ixzz2ClGwqj4B

20. Pokidysheva, L.I. Otsenka stepeni integratsii funktsional'nykh system pri nagruzochnykh testakh [Assessment of the degree of integration of functional systems during the load tests]. Thesis of Dissertation of Candidate of Medical Sciences. Krasnoyarsk, KSTU Publishing Center,1996. 23 p.

21. Pokidysheva, L.I., Ignatova, I.A. (2011). Korreliatsionnaia adaptometriia i metod glavnykh component $\mathrm{v}$ otsenke vozmozhnostei raboty immunnoi sistemy [Correlation adaptometry and principal components method in evaluating the capacity of the immune system]. Sistemnyi analiz $i$ upravlenie $v$ biomeditsinskikh sistemakh (System analysis and management in biomedical systems), Vol. 10, No. 1. Pp. $152-157$.

22. Ponomareva, L.P., Tavartkiladze, G.A., Kilikovskii, V.V. Novye podkhody k audiologicheskomu skriningu novorozhdennykh detei [New approaches to the hearing screening of newborns]. Metodologicheskie rekomendatsii № 2001/ 174 (Guidelines № 2001/ 174). M., 2003.

23. Radchenko, S.G. Ustoichivye metody otsenivaniia statisticheskikh modelei: monografiia [Sustainable methods for estimating statistical models: Monograph]. K., PP “Sansparel”, 2005. $504 \mathrm{p}$.

24. Sedov, K.R., Gorban', A.N., Petushkova, E.V., Manchuk V.T., Shalamova, E.N. (1988). Korreliatsionnaia adaptometriia kak metod dispanserizatsii naseleniia [Correlation adaptometry as a method of medical examination of the population]. Vestnik AMN SSSR (Bulletin of Academy of Medical Sciences of the USSR), No. 10. P.69.

25. Tavartkiladze, G.A. (1993). Zaderzhannaia vyzvannaia otoakusticheskaia emissiia i mekhanizmy ee generatsii [Delayed evoked otoacoustic emission and mechanisms of its generation]. Sovremennye problemy fiziologii i patologii slukha (Modern problems of physiology and pathology of hearing) ed. by G.A. Tavartkiladze, G.I. Frolenkov, A.V. Kruglov. M., 62 p. 


\title{
Увлечение современных школьников наушниками. Каковы последствия?
}

\author{
И.А. Игнатова ${ }^{\mathrm{a}, \tilde{0}, \mathrm{~B}}$, С.Н. Шилов ${ }^{\mathrm{B}}$, \\ С.Г. Вахрушев ${ }^{\boldsymbol{\sigma}}$, Л.И. Покидышева \\ ${ }^{a}$ Научно-исследовательский институт медицинских проблем Севера \\ Россия, 660022, Красноярск, ул. Партизана Железняка, 32 \\ ${ }^{6}$ Красноярский государственный медицинский университет \\ им. проф. В.Ф. Войно-Ясенецкого \\ Россия, 660022, Красноярск, ул. Партизана Железняка, 1 \\ ${ }^{6}$ Красноярский государственный педагогический университет \\ им. В.П. Астафьева \\ Россия, 660049, Красноярск, ул. Лебедевой, 89 \\ ${ }^{2}$ Сибирский федеральный университет \\ Россия, 660041, Красноярск, пр. Свободный, 79
}

\begin{abstract}
Статья посвящена исследованию выявления факторов, влияющих на проявление тугоухости среди школьников: состояние слизистой оболочки верхних дыхательных путей, возраст, беспокойство и стресс, количество часов просмотра телевизора в день (прослушивание громкой музыки и использование наушников).

С помошью математического метода корреляционной адаптометрии выявлено наличие достоверной корреляционной связи между обнаруженными особенностями патологии органа слуха среди школьников (форма, стадия тугоухости) и возрастом школьников, соматическим статусом, неврологическим статусом, а также степенью психоэмоциональных нагрузок. Сведения могут быть полезны для психологов, оториноларингологов, сурдологов, педиатров.

Ключевые слова: дети, тугоухость, факторы риска, икольники.

Исследование выполнено при финансовой поддержке РГНФ и Красноярского края в рамках научного проекта № 15-16-24007 «Комплексные исследования коренных малочисленных народов арктической зоны Восточной Сибири в области фундаментальной медицины, дистаниионной педагогики, сочиально-культурной и экономической деятельности».
\end{abstract}

Научная специальность: 13.00.00 - педагогические науки. 